Jurnal Adat dan Budaya, Vol 3, No 1 Tahun 2021

ISSN: E-ISSN 2615-6156, P-ISSN: 2615-6113

Jurnal Homepage: https://ejournal.undiksha.ac.id/index.php/JABI/index

\title{
FOLKLOR LISAN TOTOKKENGAN DI PULAU SAPEKEN, KABUPATEN SUMENEP
}

\author{
Vigor Vagori1 ${ }^{1}$ Ida Ayu Made Darmayanti2 ${ }^{2}$ Putu Mas Dewantara ${ }^{3}$ \\ 123Pendidikan Bahasa dan Sastra Indonesia, Universitas Pendidikan Ganesha, Bali, Indonesia \\ e-mail: vigor.igha96@gmail.com
}

\begin{abstract}
Abstrak
Penelitian ini bertujuan mendeskripsikan bentuk, kategori, dan fungsi Totokkengan di Pulau Sapeken, Kabupaten Sumenep. Penelitian ini dianalisis menggunakan bentuk deskriptif kualitatif. Subjek penelitian ini, yakni informan di Pulau Sapeken, Kabupaten Sumenep. Hasil penelitian Totokkengan di Pulau Sapeken, Kabupaten Sumenep dapat disimpulkan sebagai berikut: pertama, bentuk Totokkengan dapat dikelompokkan menjadi lima, yaitu: (1) pertanyaan yang bersifat teka-teki atau disebut juga pertanyaan yang cerdik, ditemukan 3 dari 42 Totokkengan; (2) pertanyaan yang bersifat permainan kata-kata, ditemukan 6 dari 42 Totokkengan; (3) pertanyaan yang bersifat permasalahan, ditemukan 5 dari 42 Totokkengan; (4) pertanyaan perangkap, ditemukan 2 dari 42 Totokkengan; dan (5) pertanyaan yang bernada lelucon, ditemukan 4 dari 42 Totokkengan. Kedua, kategori Totokkengan dapat dikelompokkan menjadi sebelas, yaitu: (1) persamaan dengan makhluk hidup, ditemukan 10 dari 42 Totokkengan; (2) persamaan dengan binatang, ditemukan 2 dari 42 Totokkengan; (3) persamaan dengan manusia, ditemukan 3 dari 42 Totokkengan; (4) persamaan dengan beberapa binatang, ditemukan 1 dari 42 Totokkengan; (5) persamaan dengan beberapa orang, ditemukan 3 dari 42 Totokkengan; (6) persamaan dengan benda, ditemukan 6 dari 42 Totokkengan; (7) persamaan dengan tanaman, ditemukan 1 dari 42 Totokkengan; (8) penambahan keterangan perumpamaan, ditemukan 6 dari 42 Totokkengan; (9) penambahan keterangan pada bentuk dan fungsi, ditemukan 1 dari 42 Totokkengan; (10) penambahan keterangan pada warna ditemukan 2 dari 42 Totokkengan; dan (11) penambahan dalam tindakan ditemukan 11 dari 42 Totokkengan. Ketiga, fungsi Totokkengan memiliki delapan fungsi, yaitu (1) untuk menguji kepandaian orang lain, (2) untuk meramal, (3) sebagai sebagian upacara perkawinan, (4) untuk mengisi waktu saat begadang menunggu jenazah dimakamkan, (5) untuk melebihi orang lain, (6) sebagai pengantar tidur, (7) hiburan, dan (8) pendidikan.
\end{abstract}

Kata Kunci: Folklor; Pulau Sapeken; Totokkengan

\begin{abstract}
This study aims to describe the form, category, and function of Totokkengan on Sapeken Island, Sumenep Regency. This study used the descriptive qualitative method. The source of this research data is informants on Sapeken Island, Sumenep Regency. The results of the Totokkengan research on Sapekan Island, Sumenep Regency can be concluded as follows: first, the Totokkengan forms can be grouped into five, namely: (1) riddle questions or also called clever questions found in 3 out of 42 Totokkengan. (2) pun questions were found 6 out of 42 Totokkengan, (3) problematic questions were found 5 out of 42 Totokkengan (4) trap questions were found 2 out of 42 Totokkengan (5) joke questions were found 4 out of 42 Totokkengan. Second, the Totokkengan category can be grouped into eleven, namely: (1) similarities with living things found 10 out of 42 Totokkengan (2) similarities with animals found 2 out of 42 Totokkengan, (3) similarities with humans found 3 out of 42 Totokkengan, (4) similarities with several animals found 1 out of 42 Totokkengan, (5) similarities with several people found 3 of 42 Totokkengan (6) similarities with objects found 6 out of 42 Totokkengans (7) similarities with plants found 1 of 42 Totokkengan (8) addition of descriptions of imagery found 6 of 42 Totokkengan, (9) addition of information on form and function found 1 of 42 Totokkengan, (10) addition of color information found 2 of 42 Totokkengan, (11) addition of action found 11 of 42 Totokkengan. Third, the function of Totokkengan has eight functions, namely (1) to test the intelligence of others, (2) to predict, (3) as part of a marriage ceremony, (4) to fill the time when staying up late waiting for the body to be buried, (5) to surpass people. others, (6) as a bedtime, (7) entertainment, and (8) education.
\end{abstract}

Keywords: Folklore; Sapeken Island; Totokkengan 


\section{PENDAHULUAN}

Kata folklor adalah pengindonesiaan dari Bahasa Inggris "folklore" yang berasal dari dua kata dasar folk dan lore. Folk adalah sinonim kolektif, yang juga memiliki pengenalan fisik atau kebudayaan yang sama, serta mempunyai kesadaran kepribadian sesuai kesatuan masyarakat. Lore adalah tradisi folk, yaitu sebagai kebudayaannya, yang diwariskan secara turun-temurun secara lisan atau melalui suatu contoh yang disertai gerak isyarat atau alat pembantu pengingat. Folklor lisan merupakan kekayaan budaya daerah yang kelestariannya ditentukan oleh pendukung budaya daerah yang bersangkutan karena folklor lisan menyimpan nilai-nilai kedaerahan dan akan memberikan sumbangsih yang sangat besar bagi pelestarian folklor lisan di daerah dan Indonesia, pada umumnya. Danandjaja (1991) mengatakan bahwa folklor secara keseluruhan adalah sebagian kebudayaan suatu kolektif yang disebarluaskan dan diwariskan turun-temurun, di antara kolektif macam tertentu, secara tradisional dalam versi yang berbeda, baik dalam bentuk lisan maupun contoh yang disertai dengan gerak isyarat atau alat pembantu pengingat (memonic device).

Sementara itu, folklor lisan yang hingga kini masih dikenal oleh masyarakat Pulau Sapeken, Kabupaten Sumenep adalah pertanyaan tradisional berupa teka-teki yang disebut Totokkengan. Meski lahir dan berkembang dalam masyarakat, Totokkengan kini seolah kehilangan jati dirinya. Totokkengan sebenarnya jika didata sangat banyak, tetapi jarang digunakan masyarakat. Hal tersebut terjadi bersamaan dengan arus globalisasi, kini manusia lebih sering berkutat dengan teknologi yang canggih. Oleh sebab itu, kelestarian Totokkengan semakin terancam. Totokkengan dapat ditemukan dalam kehidupan masyarakat Pulau Sapeken, Kabupaten Sumenep, tetapi Totokkengan tersebut sudah jarang digunakan oleh masyarakat, khususnya generasi muda karena Totokkengan sudah dianggap kuno. Tidak semua orang dapat menyampaikan Totokkengan, hanya orang yang pandai dalam mempermainkan kata-katalah yang mampu. Totokkengan bisa dibuat di berbagai tempat dan setiap saat atau boleh dikatakan tidak mengenal waktu.

Totokkengan tampaknya berada di ambang kepunahan karena hanya segelintir orang yang masih memiliki kepedulian terhadap folklor lisan tersebut. Bila tanpa adanya dukungan dari masyarakat setempat, foklor lisan akan hilang tanpa bekas dan masyarakat akan kehilangan identitas budayanya sendiri. Hal itu tampaknya juga terjadi pada Totokkengan yang hidup dan berkembang di Pulau Sapeken, Kabupaten Sumenep yang seharusnya menjadi salah satu sumbu peradaban, kini mengalami kemunduran sehingga masyarakat penikmatnya kesulitan mendapatkan literatur Totokkengan di daerah tersebut. Kekayaan dan khazanah folklor lisan di Pulau Sapeken, Kabupaten Sumenep yang menjadi peninggalan generasi sebelumnya bukan sekadar lirik yang disampaikan secara lisan maupun tulisan, melainkan di balik itu, yakni nilai-nilai yang terkandung di dalamnya merupakan ajaran atau ilmu tentang nilai kehidupan manusia. Oleh sebab itu, folklor lisan di pulau ini patut dipelajari ataupun diteliti.

Adapun masalah yang diangkat dalam penelitian ini adalah bentuk, kategori, dan fungsi Totokkengan di Pulau Sapeken, Kabupaten Sumenep. Tujuan penelitian ini adalah untuk mendeskripsikan bentuk, kategori, dan fungsi Totokkengan di Pulau Sapeken, Kabupaten Sumenep. Manfaat penelitian ini adalah hasil penelitian ini diharapkan dapat memperluas khazanah ilmu pengetahuan, terutama bidang sastra, yaitu folklor lisan yang membuktikan bahwa Totokkengan bukan hanya menjadi hiburan melainkan juga menjadi sumber belajar. Teori yang berkaitan dengan folklor lisan adalah hakikat, bentuk, ciri-ciri, fungsi folklor, dan juga Totokkengan.

\section{METODE}

Metode yang digunakan dalam penelitian ini adalah metode deskriptif, yaitu metode yang bersifat memaparkan data yang berupa uraian kata bukan angka-angka atau cara kuantitatif lainnya. Menurut Bogdan dan Taylor (dalam Moleong, 2014), penelitian kualitatif adalah prosedur penelitian yang menghasilkan data deskriptif berupa kata-kata tertulis atau lisan orang-orang dan perilaku yang dapat diamati. Metode ini digunakan untuk mendeskripikan data Totokkengan di Pulau Sapeken, Kabupaten Sumenep.

Sumber data dalam penelitian ini adalah masyarakat Pulau Sapeken yang dituturkan langsung. Informan penelitian ini ditentukan berdasarkan teknik purposive sampling. Menurut Sugiyono (2016), purposive sampling adalah teknik penentuan sampel dengan pertimbangan 
tertentu. Alasan peneliti menggunakan teknik purposive sampling tersebut karena penentuan informan terlebih dahulu harus memenuhi persyaratan. Berdasarkan penjelasan tersebut, persyaratan bagi calon informan sebagai berikut: (a) usia relatif cukup tua, yaitu berkisar 40-70 tahun dengan anggapan bahwa informan itu telah mengenal seluk beluk lingkungannya serta menguasai kosa kata bahasa daerahnya dengan baik; (b) paling sedikit terpengaruh bahasa di luar bahasa ibu; (c) informan berasal dari desa atau daerah penelitian; (d) informan lahir dan dibesarkan serta menikah dengan orang berasal dari daerah penelitian; (e) informan berada di tempat penelitian dan jarang meninggalkan daerahnya, serta (f) informan sehat jasmani dan rohani. Adapun data dalam penelitian ini adalah kata-kata dan keseluruhan Totokkengan dari hasil rekaman peneliti terhadap informan, yaitu bentuk, kategori dan fungsi Totokkengan di Pulau Sapeken, Kabupaten Sumenep.

Teknik pengumpulan data yang digunakan adalah observasi, wawancara, transkripsi dan dokumentasi. Peneliti menanyakan Totokkengan yang informan punya dan sekaligus dijawab informan dalam Bahasa Sapeken. Data yang telah diperoleh akan dianalisis dalam beberapa tahap, yaitu: tahap identifikasi data, klasifikasi data, dan penyimpulan data. Data yang dikumpulkan dari informan diidentifikasi menurut kelompok masing-masing. Lalu, data diklasifikasikan dan terakhir data disimpulkan.

\section{HASIL DAN PEMBAHASAN}

Penelitian ini dilaksanakan di Pulau Sapeken, Kabupaten Sumenep. Penelitian ini melibatkan informan yang terdiri atas 3 orang, yaitu Wa' Muhiddin, 62 tahun, Hasani Hamzah, 47 tahun, Wa' Gusni, 59 tahun, dan beberapa masyarakat Pulau Sapeken. Dari hasil penelitian yang ditemukan, ada 42 Totokkengan, yang berkaitan dengan (1) bentuk Totokkengan yang dibagi menjadi lima bentuk, yaitu: pertanyaan yang bersifat teka-teki atau disebut juga pertanyaan yang cerdik ditemukan 3 dari 42 Totokkengan; pertanyaan yang bersifat permainan kata-kata ditemukan 6 dari 42 Totokkengan; pertanyaan yang bersifat permasalahan ditemukan 5 dari 42 Totokkengan; pertanyaan perangkap ditemukan 2 dari 42 Totokkengan; pertanyaan yang bernada lelucon ditemukan 4 dari 42 Totokkengan, (2) kategori Totokkengan yang dibagi menjadi sebelas kategori, yaitu: persamaan dengan makhluk hidup ditemukan 10 dari 42 Totokkengan; persamaan dengan binatang ditemukan 2 dari 42 Totokkengan; persamaan dengan manusia ditemukan 3 dari 42 Totokkengan; persamaan dengan beberapa binatang ditemukan 1 dari 42 Totokkengan; persamaan dengan beberapa orang ditemukan 3 dari 42 Totokkengan; persamaan dengan benda ditemukan 6 dari 42 Totokkengan; persamaan dengan tanaman ditemukan 1 dari 42 Totokkengan; penambahan keterangan perumpamaan ditemukan 6 dari 42 Totokkengan; penambahan keterangan pada bentuk dan fungsi ditemukan 1 dari 42 Totokkengan; penambahan keterangan pada warna ditemukan 2 dari 42 Totokkengan, dan penambahan dalam tindakan ditemukan 11 dari 42 Totokkengan, (3) fungsi Totokkengan dibagi menjadi 8 fungsi, yaitu: untuk menguji kepandaian orang lain, untuk meramal, sebagai sebagian upacara perkawinan, untuk mengisi waktu saat begadang menunggu jenazah dimakamkan, untuk melebihi orang lain, sebagai pengantar tidur, hiburan, dan pendidikan.

\subsection{Bentuk-Bentuk Totokkengan di Pulau Sapeken Kabupaten Sumenep}

a. Pertanyaan yang bersifat teka-teki atau disebut juga pertanyaan yang cerdik adalah Totokkengan yang jawabannya tidak dapat diramalkan sebelumnya.

(1) Tokkeh-tokkeh kau, laggakne kadiya, ditangar ye kadiyata. Aine?

\section{Gentin Ruma}

Coba tebak. Jatuhnya ke bawah, tetapi dicari di atas. Apakah itu?

Genteng Rumah

(2) Tokkeh-tokkeh kau. Bua ai lamun laggak, laggakne kadiyata. Aine?

Samo

Coba tebak. Buah apa yang ketika jatuh, jatuhnya ke atas?

Samo (Buah dari pohon yang tumbuh didasar laut)

(3) Tokkeh-tokkeh kau. Tagahnu ingkoku, aku na tuhun. Aine?

Gayoh

Coba tebak. Kau pegangi ekorku, saat aku ingin menyelam. Apakah itu?

Gayung 
b. Pertanyaan yang bersifat permainan kata-kata adalah pertanyaan Totokkengan yang terbentuk dari permainan kata-kata yang lucu.

(1) Tokkeh-tokkeh kau. Ellehne nggai di kadampahan elle aha dadunniye, sampe-sampe ahaaha iru ngalappak didirine. Aine?

Lamenggat

Coba tebak. Suaranya tidak disenangi semua orang yang ada di dunia, bahkan orang-orang menampar dirinya sendiri. Apakah itu?

Nyamuk

(2) Tokkeh-tokkeh kau. Nai ne niya matikolokne, tanganne niya matikolokne, badanne niya matikolokne, tikolokne niya ma tikolokne. Aine?

Kutu

Coba tebak. Kakinya ada di kepala, tangannya ada di kepala, badannya ada di kepala, kepalanya ada di kepala. Apakah itu?

Kutu

(3) Tokkeh-tokkeh kau. Di pugai elle aha sappulu, dilembar elle aha duangan. Aine?"

Roko

Coba tebak. Sepuluh orang yang membuatku, dua orang yang memanggulku. Apakah aku?

Rokok

c. Pertanyaan yang bersifat permasalahan adalah Totokkengan yang berhubungan dengan ilmu hitung dan pertanyaan praktis. Sifat pertanyaannya dapat sungguh-sungguh atau hanya untuk mengganggu orang lain saja.

(1) Tokkeh-tokkeh kau. Aku karungayan. Kau ringit. Aine?

Bau entut

Coba tebak. Aku kehilangan. Kamu merasa yang marah. Apakah itu?

Bau kentut

(2). Tokkeh-tokkeh kau. Dipasak, niya maluwahan ye, dipalua niya maluwahan ye. Aine?

Kanceh badu

Coba tebak. Dimasukkan, dia ada di luar, dikeluarkan dia tetap di luar. Apakah itu?

Kancing baju

(3). Tokkeh-tokkeh kau. Di baba ye nangis, dipalempar dian ye. Aine

Jareh

Coba tebak. Digendong menangis, diletakkan dia diam. Apakah itu?

Jaring ikan

d. Pertanyaan perangkap adalah Totokkengan bentuk lain, yang dipergunakan untuk membuat orang yang kurang waspada malu karena terperdaya.

(1) Tokkeh-tokkeh kau. Bulu aine tau uye?

Bulurah

Coba tebak. Bulu, bulu apa yang bisa nyanyi?

Bu Lurah

(2) Tokkeh-tokkeh kau. Dayah, dayah ai matene dakau?

Gambar dayah

Coba tebak. Ikan, ikan apa yang memiliki mata hanya satu?

Foto ikan

e. Pertanyaan yang bernada lelucon adalah Totokkengan yang termasuk jenis ini, yakni lelucon mengenai orang idiot.

(1) Tokkeh-tokkeh kau. Aha botak iru disimboloh. Aine?

Bobondeh

Coba tebak. Orang botak di kepang rambutnya. Apakah itu?

Balon

(2) Tokkeh-tokkeh kau. Kuleberne niya madiyalan. Gigine niya maluwahan. Aine? 
Jurnal Adat dan Budaya Vol. 3, No. 1, Tahun 2021, pp. 36-44

Kime

Coba tebak. Bibirnya ada di dalam, giginya ada di luar. Apakah itu?

Kima

(3) Tokkeh-tokkeh kau. Aha bongkok nyompo aha lime. Aine?

Kokocak

Coba tebak. Orang bungkuk menggendong lima orang. Apakah itu?

Ulekan

\subsection{Kategori-Kategori Totokkengan di Pulau Sapeken Kabupaten Sumenep}

a. Persamaan dengan makhluk hidup

Totokkengan dapat digolongkan ke dalam kategori persamaan dengan makhluk hidup apabila unsur pelukisan pertanyaannya mengandung persamaan dengan makhluk hidup.

(1) Tokkeh-tokkeh kau. iye samatah moe rumane penje-penje. Aine?

Kalimomah

Coba tebak. Ia selalu membawa rumahnya kemana-mana. Apakah itu?

Kelomang

(2) Tokkeh-tokkeh kau. Nai ne niya matikolokne, tanganne niya matikolokne, badanne niya matikolokne, tikolokne niya ma tikolokne. Aine?

Kutu

Coba tebak. Kakinya ada di kepala, tangannya ada di kepala, badannya ada di kepala, kepalanya ada di kepala. Apakah itu?

Kutu

(3) Tokkeh-tokkeh kau. Sisikan nggai ye dayah, dipanyongan nggai ye datu?

Nanas

Coba tebak. Bersisik bukannya ikan, dipayungi bukannya raja?

Buah Nanas

b. Persamaan dengan binatang

Totokkengan dapat digolongkan ke dalam kategori persamaan dengan binatang apabila unsur pelukisan pertanyaannya mengandung persamaan dengan binatang

(1) Tokkeh-tokkeh kau. Sisikan nggai ye dayah, dipanyongan nggai ye datu?

Nanas

Coba tebak. Bersisik bukannya ikan, dipayungi bukannya raja?

Buah nanas

(2) Tokkeh-tokkeh kau. Hewan aine paleng susugian?

Beruang

Coba tebak. Hewan apa yang paling kaya?

Beruang.

c. Persamaan dengan manusia

Totokkengan dapat digolongkan ke dalam kategori persamaan dengan manusia apabila unsur pelukisan pertanyaannya mengandung persamaan dengan manusia.

(1) Tokkeh-tokkeh kau. Emmane disasapu, anakne dititindak. Aine?

Tangge

Coba tebak. Ibunya dielus-elus, sedangkan anaknya diinjak-injak. Apakah itu?

Tangga

(2) Tokkeh-tokkeh kau. Aha botak iru disimboloh. Aine?

Bobondeh

Coba tebak. Orang botak dikepang rambutnya. Apakah itu?

Balon

(3) Tokkeh-tokkeh kau. Bulu-bulu palese sibotak na palua. Aine?

Bua buluwan.

Coba tebak. Bulu-bulu minggir, si botak mau keluar. Apakah itu?

Buah rambutan 
d. Persamaan dengan beberapa binatang

Totokkengan dapat digolongkan ke dalam kategori persamaan dengan beberapa binatang apabila unsur pelukisan pertanyaannya mengandung persamaan dengan beberapa binatang.

(1) Tokkeh-tokkeh kau. Sinakan dakumpal pupurungan tungai. Aine?

Salak

Coba tebak. Nasi sekepal dikerumuni tungau. Apakah itu?

Buah salak

e. Persamaan dengan beberapa orang

Totokkengan dapat digolongkan ke dalam kategori persamaan dengan beberapa orang apabila unsur pelukisan pertanyaannya mengandung persamaan dengan beberapa orang.

(1) Tokkeh-tokkeh kau. Di pugai elle aha sappulu, dilembar elle aha duangan. Aine?" Roko

Coba tebak. Sepuluh orang yang membuatku, dua orang yang memanggulku. Apakah aku? Rokok

(2) Tokkeh-tokkeh kau. Aha bongkok nyompo aha lime. Aine?

Kokocak

Coba tebak. Orang bungkuk menggendong lima orang. Apakah itu?

Ulekan

f. Persamaan dengan benda

Totokkengan dapat digolongkan ke dalam kategori persamaan dengan benda apabila unsur pelukisan pertanyaannya mengandung persamaan dengan benda.

(1) Tokkeh-tokkeh kau. Sampak aha takitenu, sampak didirinu nggai takitenu. Aine?

Gigi

Coba tebak. Pagar orang bisa kamu lihat, pagar sendiri tidak bisa kamu lihat. Apakah itu?

Gigi

(2) Tokkeh-tokkeh kau. Lumboh datu nggai kole diguguran gusoh. Aine?

Mate

Coba tebak. Sumur raja tidak boleh ditaburi pasir. Apakah itu?

Mata

(3) Tokkeh-tokkeh kau. Bujjak datu nggai kole di pekkas. Aine?

Boe uran

Coba tebak. Tongkat raja tidak bisa diikat. Apakah itu?

Air hujan

g. Persamaan dengan tanaman

Totokkengan dapat digolongkan ke dalam kategori persamaan dengan tanaman apabila unsur pelukisan pertanyaannya mengandung persamaan dengan tanaman.

(1) Tokkeh-tokkeh kau. Bua ai lamun laggak, laggakne kadiyata. Aine?

Samo

Coba tebak. Buah apa yang ketika jatuh, jatuhnya ke atas?

Samo (buah dari tumbuhan yang hidup di dasar laut)

h. Pertambahan keterangan perumpamaan

Totokkengan dapat digolongkan ke dalam kategori pertambahan keterangan perumpamaan apabila unsur pelukisan pertanyaannya mengandung penambahan keterangan perumpamaan.

(1) Tokkeh-tokkeh kau. Galoro madiya, karangan madiyata. Aine?

Ngukkus sinakan

Coba tebak. Di bawah berombak, di atas berkarang. Apakah itu?

Mengukus Nasi

(2) Tokkeh-tokkeh kau. Papan diyata, papan diya, matetenggane api narake. Aine? 
Jurnal Adat dan Budaya Vol. 3, No. 1, Tahun 2021, pp. 36-44

Tindisan dadaulu

Coba tebak. Di atas papan, di bawah papan, ditengah-tengahnya api neraka. Apakah itu?

Setrika zaman dulu

(3) Tokkeh-tokkeh kau. Di baba ye nangis, dipalempar dian ye. Aine

Jareh

Coba tebak. Digendong menangis, diletakkan dia diam. Apakah itu?

Jaring ikan

i. Pertambahan keterangan pada bentuk dan fungsi

Totokkengan dapat digolongkan ke dalam kategori pertambahan keterangan bentuk dan fungsi apabila unsur pelukisan pertanyaannya mengandung pertambahan keterangan bentuk dan fungsi.

(1) Tokkeh-tokkeh kau. Dipasak ye palantas. Dipalua ye pabengkok. Aine?

Aha ngorek tai uroh

Coba tebak. Di luruskan jika dimaksukan, jika dikeluarkan di bengkokkan. Apakah itu?

Orang lagi ngupil

j. Pertambahan keterangan pada warna

Totokkengan dapat digolongkan ke dalam kategori penambahan keterangan pada warna apabila unsur pelukisan pertanyaannya mengandung penambahan keterangan pada warna.

(1) Tokkeh-tokkeh kau. Masi ngura ye makai bidah nyuloh, lamun towe ye makai bidah mire. Aine?

Cabi

Coba tebak. semasa ia muda bersarung hijau, semasa tua bersarung merah. Apakah itu?

Cabai

(2) Tokkeh-tokkeh kau. Badanne nyuloh, tikolokne mire, lene numalan pasuhut kabuliyan jangke puppus. Aine?"

Obat nyamuk

Coba tebak. Badannya hijau, kepalanya merah, berjalan mundur. Apakah itu?

Obat nyamuk

k. Penambahan dalam tindakan

Totokkengan dapat digolongkan ke dalam kategori pertambahan keterangan dalam tindakan apabila unsur pelukisan pertanyaannya mengandung penambahan keterangan dalam tindakan.

(1) Tokkeh-tokkeh kau, Lamung tumbah dakau, tumbah memong. Aine?

Aha sambayah jama'ah

Coba kamu tebak. Menumbangkan satu orang, semua orang tertumbangkan. Apakah itu?

Orang sholat berjama'ah

(2) Tokkeh-tokkeh kau. Dibowahan aku tepoku, mawattu aku na tidor. Aine?

Aha Malenan

Coba tebak. Dia membawakan tikar kepadaku ketika aku ingin tidur. Apakah itu?

Orang meninggal

(3) Tokkeh-tokkeh kau. Perkkaranne lamakne, ulananne kamodine. Aine?

Mamanok lumeyah

Coba tebak. Dia membentangkan layar saat komudinya diangkat. Apakah itu?

Burung terbang

\subsection{Fungsi Totokkengan di Pulau Sapeken Kabupaten Sumenep}

a. Fungsi Totokkengan untuk menguji kepandaian orang lain adalah diisebutkan kepandaian seseorang dan bukan kecerdasan seseorang karena dalam kenyataan, banyak folklor lisan Totokkengan tidak dapat dijawab dengan daya pikir saja, tetapi jawabannya harus diketahui lebih dahulu. Memang untuk menguasai pengetahuan suatu Totokkengan, kita bukan saja mengetahui pertanyaannya, melainkan juga harus mengetahui jawabannya. Hal ini 
disebabkan oleh kebanyakan yang dilukiskan di dalam pertanyaan bersifat kiasan. Akibatnya, hampir tidak mungkin bagi seseorang untuk dapat menjawab suatu pertanyaan dalam folklor lisan Totokkengan tanpa pernah mengetahui terlebih dahulu jawaban yang tepat. Oleh karena itu, orang yang banyak mengetahui Totokkengan akan mendapatkan kepuasan karena akan terkenal sebagai orang yang pandai dan berpengetahuan luas mengenai folklor lisan Totokkengan.

b. Fungsi Totokkengan untuk meramal rupanya dulu pertanyaan tradisional juga berfungsi meramalkan sesuatu kejadian yang belum terjadi

c. Fungsi Totokkengan sebagai sebagian upacara perkawinan di Pulau Sapeken, Kabupaten Sumenep, Totokkengan termasuk sebagai bagian dari upacara perkawinan.

d. Fungsi Totokkengan untuk mengisi waktu saat begadang menunggu jenazah dimakamkan Totokkengan menjadi kegiatan yang selalu dilakukan oleh masyarakat Pulau Sapeken, Kabupaten Sumenep untuk mengisi waktu senggang saat begadang menunggu jenazah yang belum ataupun sudah dimakamkan.

e. Fungsi Totokkengan untuk melebihi orang lain. Hal ini juga berlaku di Pulau Sapeken, Kabupaten Sumenep saat Totokkengan dilakukan, baik anak-anak, remaja maupun orang tua yang terlibat di dalam Totokkengan akan saling bersaing untuk menebak jawaban yang tepat dari pertanyaan yang diberikan untuk melebihi orang-orang terlibat di dalam permainan Totokkengan tersebut.

f. Fungsi Totokkengan sebagai pengantar tidur. Para orang tua selalu memberikan pertanyaan atau Totokkengan kepada anaknya ketika beranjak tidur.

g. Fungsi Totokkengan sebagai hiburan. Totokkengan juga menjadi salah satu hiburan bagi masyarakat di Pulau Sapeken, Kabupaten Sumenep yang mayoritas nelayan

Fungsi Totokkengan sebagai pendidikan. Totokkengan sebagai media pendidkan karena selain melatih daya pikir seseorang, di dalam Totokkengan baik dari pertanyaan maupun jawaban mengandung nilai-nilai kebaikan serta larangan-larangan yang harus dilakukan mulai dari diri sendiri.

\section{SIMPULAN}

Berdasarkan hasil penelitian terhadap bentuk, kategori dan fungsi Totokkengan di Pulau Sapeken, Kabupaten Sumenep yang berjumlah 42 Totokkengan, yang berkaitan dengan (1) bentuk Totokkengan yang dibagi menjadi lima bentuk, yaitu: pertanyaan yang bersifat teka-teki atau disebut juga pertanyaan yang cerdik ditemukan 3 dari 42 Totokkengan; pertanyaan yang bersifat permainan kata-kata ditemukan 6 dari 42 Totokkengan; pertanyaan yang bersifat permasalahan ditemukan 5 dari 42 Totokkengan; pertanyaan perangkap ditemukan 2 dari 42 Totokkengan; pertanyaan yang bernada lelucon ditemukan 4 dari 42 Totokkengan, (2) kategori Totokkengan yang dibagi menjadi sebelas kategori, yaitu: persamaan dengan makhluk hidup ditemukan 10 dari 42 Totokkengan; persamaan dengan binatang ditemukan 2 dari 42 Totokkengan; persamaan dengan manusia ditemukan 3 dari 42 Totokkengan; persamaan dengan beberapa binatang ditemukan 1 dari 42 Totokkengan; persamaan dengan beberapa orang ditemukan 3 dari 42 Totokkengan; persamaan dengan benda ditemukan 6 dari 42 Totokkengan; persamaan dengan tanaman ditemukan 1 dari 42 Totokkengan; penambahan keterangan perumpamaan ditemukan 6 dari 42 Totokkengan; penambahan keterangan pada bentuk dan fungsi ditemukan 1 dari 42 Totokkengan; penambahan keterangan pada warna ditemukan 2 dari 42 Totokkengan, dan penambahan dalam tindakan ditemukan 11 dari 42 Totokkengan, (3) fungsi Totokkengan dibagi menjadi 8 fungsi, yaitu: untuk menguji kepandaian orang lain, untuk meramal, sebagai sebagian upacara perkawinan, untuk mengisi waktu saat begadang menunggu jenazah dimakamkan, untuk melebihi orang lain, sebagai pengantar tidur, hiburan, dan pendidikan.

Adapun saran setelah pelaksanaan penelitian untuk skripsi yang dilakukan sebagai berikut. Hendaknya, pemerintah dapat mengangkat dan mengenalkan folklor lisan Totokkengan di Pulau Sapeken, Kabupaten Sumenep sebagai budaya lokal dan dikenalkan pada masyarakat pada umumnya sehingga masyarakat umum bisa mengenal folklor lisan Totokkengan. 


\section{DAFTAR PUSTAKA}

Danandjaja, James. 1991. Folklor Indonesia (Ilmu Gosip, Dongeng, dan lain-lain). Jakarta: Pustaka Utama Grafiti.

Moleong, Lexy J. 2014. Metode Penelitian Kualitatif. Bandung: Remaja Rosdakarya.

Sugiyono. 2008. Metode Penelitian Pendidikan (Pendekatan Kuantitatif, Kualitatif, dan R\&D). Bandung: Alfabeta.

Sugiyono. 2016. Metode Penelitian Pendidikan (Pendekatan Kuantitatif, Kualitatif dan R\&D). Bandung: Alfabeta. 